REVIEW ARTICLE

\title{
Leishmania tropica (Kinetoplastida: Trypanosomatidae) - a perplexing parasite
}

\author{
Raymond L. Jacobson
}

Department of Parasitology, The Hebrew University-Hadassah Medical School, P.O. Box 12272, Jerusalem, 91120, Israel

Key words: Leishmania tropica, Phlebotomus, cutaneous leishmaniasis

\begin{abstract}
Leishmania tropica is one of the causative agents of cutaneous leishmaniasis (CL), a disfiguring parasitic disease that recently was found to be viscerotropic. In urban areas it is transmitted from infected individuals by the bite of phlebotomine sand flies to naïve persons (anthroponotic CL). In rural areas animals are thought to be the reservoir, but the full life cycle is still under investigation (zoonotic CL). For many years L. tropica was either confused or merely grouped with L. major while Phlebotomus sergenti was the only proven vector. In recent years new foci have erupted, but few have been investigated. This review describes some of the history, recent findings, epidemiology, potential vectors, and the search for possible reservoir hosts besides man.
\end{abstract}

\section{BACKGROUND}

Species of Leishmania Ross, 1903 are digenetic (heteroxenous) parasitic protozoa of humans and animals that are found alternatively as flagellated, motile promastigotes in the alimentary tract of phlebotomine sand flies, or as obligate intracellular aflagellate amastigotes in the phagolysosomes of mammalian host macrophages. There are over 25 designated species plus several unnamed species grouped into two subgenera, (Lainson and Shaw 1987, Jacobson 1994). The leishmaniases are now endemic in 88 countries on five continents - Africa, Asia, Europe, North America, and South America - with a total of 350 million people at risk. It is believed that worldwide 12 million people are affected by leishmaniasis. This often-quoted figure includes cases with overt disease, as well as those with no apparent symptoms. Of the 1.5-2 million new cases of leishmaniasis estimated to occur annually, only 600,000 are officially declared. Nearly $90 \%$ of all cases of CL occur in Afghanistan, Brazil, Iran, Peru, Saudi Arabia and Syria.

Leishmaniasis presents in four different forms with a broad range of manifestations: Visceral leishmaniasis (VL, kala azar) is the most severe form and if untreated has a mortality rate approaching $100 \%$. This form is characterized by fever, weight loss, enlargement of the spleen and liver and anaemia. Mucocutaneous leishmaniasis (MCL) produces lesions which can lead to extensive and disfiguring destruction of mucous membranes of the nose, mouth and throat cavities. Cutaneous leishmaniasis (CL) manifests with sores or ulcers on exposed parts of the body such as arms, legs and face which may heal spontaneously, but the diffuse form of CL does not heal and may relapse after treatment. AIDS and other immunosuppressive conditions increase the risk of Leishmania-infected people developing the visceral illness. In certain areas of the world the risk of coinfection with HIV is rising due to epidemiological changes.

In the Old World, cutaneous leishmaniasis can be caused by four parasites: L. aethiopica Bray, Ashford et Bray, 1973, which is restricted to East Africa, and $L$. major Yakimoff et Schokor, 1914 emend. Bray, Ashford et Bray, 1973, which is found in desert and savannah regions from North Africa, the Middle East, and Central Asia to the Indian subcontinent. The third parasite is L. infantum Nicolle, 1908, which in most patients infected causes visceral leishmaniasis, but asymptomatic, cutaneous, mucocutaneous, diffuse cutaneous, and post-kala-azar dermal leishmaniasis can be produced by this parasite (Alvar et al. 1997). The fourth parasite, L. tropica (Wright, 1903), is the subject of this review.

\section{HISTORY}

The human protozoan parasite that we now know as Leishmania tropica has undergone several name changes since it was first described. One hundred years ago, Wright (1903) working in Boston, described the parasites taken from a lesion of an Armenian girl and identified them as Helcosoma tropicum. His description and pictures of the amastigotes in macrophages are as relevant today as a century ago. He was perhaps unaware that Ross (1903) had already designated the genus Leishmania, and so the taxonomy was emended three years later in a German textbook on tropical medicine (Lühe 1906). To add to the confusion there appeared to be two forms of the parasite causing cutaneous leishmaniasis, one with larger amastigotes and one with smaller amastigotes. Two Russian authors, 
while describing parasites taken from a lesion of a dog in Tashkent, Uzbekistan decided that the parasites should be known as L. tropica minor (small amastigotes, as seen in Bukhara) and L. tropica major (large amastigotes, as seen in Termes, now Termiz) (Yakimoff and Schokhor 1914). Although this became the standard designation for the next 60 years, the authors were simply trying to describe a new species, in just over a page of text, L. tropica var. canina, isolated from a dog. The new species name was never accepted. A long list of invalid names suggested for this parasite was reported by Lainson and Shaw (1987), including the inappropriately named Plasmosoma jerichoense Huntemueller, 1914 nec P. jerichaense Kirk, 1949. This ambiguity over the correct name of the parasite led to even more confusion in the literature as later researchers were forever unsure which of the two L. tropica subspecies was the subject of the earlier research papers.

In 1973, Bray et al. described a new species causing cutaneous leishmaniasis in Ethiopia which they designated $L$. aethiopica. In reviewing the literature these authors then raised $L$. major to a specific rank for the parasite causing zoonotic cutaneous leishmaniasis (ZCL) in Central Asia. They left the L. tropica of the Middle East and Africa as previously described, little knowing that the L. major of Central Asia was much closer to the parasite causing CL in Africa, the Middle East and India. The term L. tropica minor was slowly phased as new biochemical techniques were applied to characterisation, and two distinct parasites were finally recognised, L. tropica causing anthroponotic urban CL (ACL) and L. major causing ZCL.

\section{GEOGRAPHICAL DISTRIBUTION}

Some of the vernacular names of CL also describe the geography; Aleppo button or boil (Syria), Delhi boil (India), Baghdad boil (Iraq), Bouton de Crete (Greek island), Ashkhabad sore (Turkmenistan), Bouton de Biskra (Algeria), Balkh sore (Afghanistan), tropical sore, etc. Although some of the names may refer to sores caused by L. major rather than L. tropica, geographically the distribution of both parasites often overlaps, though not contiguously.

The western limit of $L$. tropica appears to be the Greek Island of Zakynthos, and foci have occurred in other Middle Eastern countries, Turkey, Syria, Jordan, Israel, and countries bordering the Mediterranean littoral, such as Morocco and Tunisia. Looking eastward from the Mediterranean foci, the disease is found in Saudi Arabia, Yemen, Iran and Iraq, where it is a very old disease, the Central Asian foci in Afghanistan and Turkmenistan and then at its eastern limit in the northwestern states of India, Punjab and Rajasthan. In Africa, south of the Sahara, new foci have been discovered in Kenya, while in Namibia an atypical form has been described.

\section{URBAN FOCI}

The famous Iraqi focus in Baghdad was intensively investigated and according to Adler and Theodor (1929), there are some quarters where "scarcely anyone escapes infection". In Kabul, Afghanistan, in 2001, it has been estimated that 270,000 people were infected in a population of less than 2 million (compared to 2,000 in 1984 and 14,153 between 1994/95), (Ashford et al. 1992, Hewitt et al. 1998, Desjeux 2001). In 1997, in a long-term Afghan refugee settlement in Pakistan, an outbreak of ACL occurred and a survey showed that $38 \%$ of the 9,200 inhabitants bore leishmanial lesions (Rowland et al. 1999). The source of the outbreak was thought to be visitors from Kabul, demonstrating that cross-border movement can be a major risk factor. In other urban centres, the number of cases are also increasing, such as in Aleppo, Syria, 3,664 in 1988 to 4,700 in 1999 (Tayeh et al. 1997, Desjeux 2001). However, in Sanliurfa in South-east Turkey, the numbers peaked in 1993 at $2,980(\approx 1 \%$ of the population $)$, but dropped to approximately 800 between 1997-2002 (Volf et al. 2002). Other population centres that have been recently reported as endemic for ACL include, Bam (1,750 cases) and Shiraz in Iran (Dowlati 1996, Sharifi et al. 1998) and Mosul in Iraq (Desjeux 2001). The older Central Asian foci appear to have diminished after the anti-malaria campaigns during the 1960s, although there are reports of reactivation of the old endemic focus in Ashkhabad, Turkmenistan, (Dobrzhanskaya et al. 1989). As recently as 1995, an active new focus of ACL was found in the northern city of Taza in Morocco, but also dogs were found infected with L. tropica (Guessous-Idrissi et al. 1997). On the Indian subcontinent, ACL can be found scattered throughout Pakistan (Munir et al. 1989) and in the north-western parts of India (Sehgal et al. 1992).

\section{RURAL FOCI}

Reports of zoonotic CL due to L. tropica are scarcer in the literature than anthroponotic CL, due mainly to the small numbers and sporadic appearance of cases involved. In Greece, which has had a long history of leishmaniases, reports confirm that the cutaneous leishmaniasis found in rural areas on the mainland, Crete and some Ionian islands was due to L. tropica (Adler et al. 1938, Garifallou et al. 1984). In Saudi Arabia, the disease is endemic in the south-western part of the country with 4,500 cases reported in 1988 , mainly from the Asir plateaux, 2,000 $\mathrm{m}$ above sea level (AlZahrani et al. 1989). The description of the non-urban nature of these infections would suggest a zoonosis, but this is not proven. The disease is endemic in Tunisia, appearing in micro-foci in the south-east of the country, where a variant new species was discovered (Rioux et al. 1986), which may also have a zoonotic cycle (Ben Ismail 1994). In Jordan, there appears to be three different foci, one in the north, around Irbid, one in the centre, around Salt, and one in the south, around Tafieleh 
(Kamhawi et al. 1995, Saliba et al. 1993, 1997). The number of cases are small in each rural area, suggesting zoonotic rather than anthroponotic foci. In Israel, new foci have been reported in the Judean Hills (15 km east of Jerusalem), in the Northern Galilee around Tiberias and in some villages north of Lake Kinneret (Sea of Galilee) (Klaus et al. 1994, Jacobson et al. 2003, Schnur et al. 2004).

In Africa south of the Sahara, the presence of $L$. tropica (sensu stricto) was not suspected until a new focus was discovered in the Rift Valley in Kenya (Mebrahtu et al. 1987, Lawyer et al. 1991, Sang 1991). In subsequent years, small rural foci were described, indicating zoonotic reservoirs rather than man to man transmission (Mebrahtu et al. 1988, Sang et al. 1994, Massamba et al. 1998). In South West Africa/Namibia there have been reports of CL occurring in very small numbers (34 diagnosed cases in 19 years) (Grove 1989) and though the parasite has been investigated, it appears to be close but not identical to L. tropica s.s. (Le Blancq and Peters 1986, Schönian et al. 2001). Another emerging focus may be in Sri Lanka where autogenous CL has been reported in a scrub jungle setting and therefore is probably zoonotic in origin (Wijesundera 2001).

\section{CLINICAL MANiFESTATIONS}

Classically, lesions caused by L. tropica in urban environments are "dry" as compared to "wet" in rural cases, but the latter usually refers to L. major cutaneous sores. These definitions are no longer exclusive and with modern diagnostic procedures, parasite identification to the species level has enabled scientists to rewrite the textbooks. The main difference appears to be the duration of the L. tropica lesion, which can persist as an erythematous papule unchanged for more than a year. In hyperendemic regions there can be multiple lesions on the exposed parts of the body. The lesions often resemble flattened volcanoes, becoming firmer as they heal and can last for more than three years (Fig. 1).

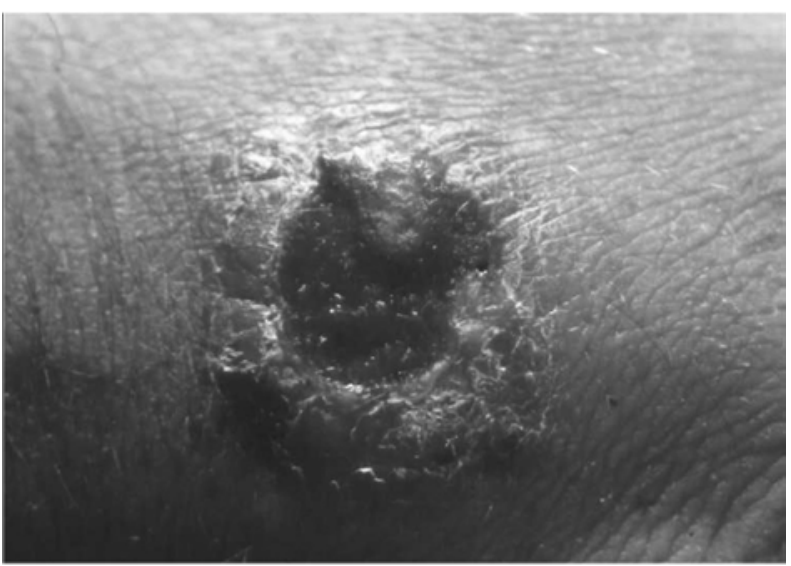

Fig. 1. Cutaneous leishmaniasis lesion on the arm of a young patient. Leishmania tropica parasites were isolated from the lesion. Actual size. Photo credit: G. Anders.
One unusual form of this disease is known as leishmaniasis recidivans, sometimes called lupoid leishmaniasis, due to its similar appearance to cutaneous tuberculosis. The lesions of these patients never heal spontaneously, spread often across the face and even with treatment may last many years. Another non-healing variety has been described where the lesion continues as erythematous boggy nodules and plaques which can be either active or quiescent, lasting many years and seen mainly in elderly patients.

Leishmania tropica has been incriminated as the causative agent of either a systemic illness or classical visceral leishmaniasis which can be fatal (Oren et al. 1991, Magill et al. 1993, 1994). While there are only very few cases actually described whose origin is irrefutable, all the above were either from Israel or Gulf War veterans. Sacks et al. (1995) found that 4 of 15 Indian patients suffering from kala-azar (visceral leishmaniasis usually associated with $L$. donovani) were actually infected with $L$. tropica. The four infected were all boys aged 8-13 living in the same district; the isolates were fresh and the methods used to characterize the infectious agent unequivocal.

These reports raise the question whether L. tropica is the causative agent of visceral leishmaniasis in other areas, but recent reports of drug resistant visceral leishmaniasis in India have failed to find any evidence of this parasite (Thakur et al. 2001, Sundar et al. 2001).

\section{VECTORS}

All Leishmania species are transmitted by female phlebotomine sand flies (Diptera, Nematocera, Psychodidae, Psychodinae). There are six genera in the subfamily Phlebotominae, of which only two are of medical importance, namely Phlebotomus Rondani et Berté, 1840 of the Old World (divided into 12 subgenera), and Lutzomyia França, 1924 of the New World (divided into 25 subgenera and species groups). All proven vectors of the leishmaniases are species of these two genera.

Both sexes require sugar meals for nutrition, but only the females engorge blood to facilitate oogenesis. Sand flies, which are very small, seldom more than $3 \mathrm{~mm}$ in body length, are crepuscular and nocturnal, spending the daylight hours in animal burrows or any crack or crevice with sufficient humidity. They have many setae, are silent and tend to hop around on a host before partaking of a blood meal. The females adopt a characteristic position with the wings angled above the abdomen as they feed by lacerating the skin with their sharp mouthparts and then sucking the blood from the pools that form from the painful wound. Phlebotomine sand flies are opportunistic feeders, but some species have been described as peri-domestic and exophilic.

The most important proven vector of $L$. tropica is the sand fly P. (Paraphlebotomus) sergenti Parrot, 1917. It is surprising how few strains of L. tropica from sand flies have been isolated and characterized. As early as 
1929, Adler and Theodor had isolated flagellates from $P$. sergenti in Iraq, and had attempted transmission studies with dogs and humans, but due to the ambiguous designation of $L$. tropica it is difficult now to determine the significance of those studies. In Saudi Arabia only two isolates were reported (Al-Zahrani et al. 1988), while in Morocco, 89 isolates were characterized (Guilvard et al. 1991). In Afghanistan, where the prolonged epidemic in Kabul was thoroughly investigated, $P$. sergenti was thought to be the main vector, but a surprising correlation was found between the presence of cases of L. tropica and P. (Phlebotomus) papatasi (Scopoli, 1786) (Ashford et al. 1992). The suggestion that $P$. papatasi could be a vector was discounted when only $6 \%$ became heavily infected in experiments with indigenous sand flies and parasites (Killick-Kendrick et al. 1994). As infection rates for $P$. papatasi with $L$. major often exceed 85\% (Schlein and Jacobson 1996), it is not surprising that $6 \%$ would be dismissed as meaningless, but infection rates from the field are often very different from the laboratory. In Israel, where we have two rural foci under investigation, infected $P$. sergenti have been found in both areas, but in the Northern Galilee focus (Fig. 2), 5\% of P. (Adlerius) arabicus Theodor, 1953 were infected compared to $1.2 \%$ of $P$. sergenti (Jacobson et al. 2003). P. (Larroussius) guggisbergi Kirk et Lewis, 1952 appears to be the main vector in Kenya (Lawyer et al. 1991), where 168/3,867 (4.3\%) were infected with L. tropica promastigotes, which were identical to human isolates from the same area. Parasites have also been isolated from $P$. (Larroussius) aculeatus Lewis, Minter et Ashford, 1974 and P. (Paraphlebotomus) saevus Parrot et Martin, 1939 in the Kenyan foci, but it is unknown whether these are primary vectors (Johnson et al. 1993, Sang et al. 1993). The exact designation of the parasite causing cutaneous leishmaniasis in Namibia is still under discussion; the identification of the sand flies (near P. (Synphlebotomus) rossi, De Meilon et Lavoipierre, 1944)) from which similar parasites have been isolated, awaits further investigation (Davidson 1993).

Currently, in many of the epidemiological studies of cutaneous leishmaniasis due to L. tropica, the presence of $P$. sergenti in the environment has suggested its vectorial role in transmission (e.g. Ashford et al. 1992, Volf et al. 2002). Recently, Kamhawi et al. (2000) have shown experimentally that $P$. sergenti is susceptible to both Afghan and Jordanian strains of L. tropica, but refractory to $L$. major and $L$. donovani. However, the fact that other subgenera, such as Adlerius and Larroussius have now been shown to harbour parasites, identical to human isolates, raises the question whether other species can also be vectors. More recently, under laboratory conditions, $P$. (Adlerius) halepensis Theodor, 1958 were found to be highly susceptible to both $L$. tropica and L. major (Sádlová et al. 2003). As this sand fly is widely distributed from Jordan and Israel to
Turkey, Iran, Transcaucasia (Azerbaijan, Armenia, Georgia), and south of Turkmenistan, its vector potential needs investigation.

\section{RESERVOIR HOSTS}

The search for reservoirs (other than man) of ACL has been intensive, but ultimately the inference must be drawn that the animals so far described are not true reservoirs, but accidental hosts. In stable human populations, where the disease is endemic, there appears to be an immune process, whereby the infection rates decrease over a period of time. In urban populations where there is a steady immigration from rural areas, the incidence of new cases is proportional with that migration. The recent epidemic in Kabul was almost certainly due to the migration of a non-immune populace from the countryside into the city following the war.

Of the animals captured that aroused the most interest are the dog and the rat, as the former lives so close to man and is a reservoir of $L$. infantum and the latter is ubiquitous. Yet the literature indicates that the dog in Syria and Morocco is as much a victim as man (Dereure et al. 1991a, b, Guessous-Idrissi et al. 1997) and that infection in rats is extremely rare, a single black rat (Rattus rattus) from Baghdad (El-Adhami 1976) and another from the Laikapa District in Kenya (Massamba et al. 1998). The Baghdad focus was intensively investigated, but even though 400 dogs and rodents were examined all were negative (Bray and Dabbagh 1968).

In rural settings, where the zoonosis is strongly suspected, the list of suspects is even more meagre, due partly because so few foci have ever been thoroughly investigated. The only feral animal, where more than one specimen has shown some suggestion of being a reservoir, is the hyrax (Fig. 3). Both in Kenya and Israel, PCR samples positive for L. tropica DNA have been obtained and partially characterized (Ashford and Sang 2001, Jacobson et al. 2003). In the Namibian focus, where the parasite causing cutaneous leishmaniasis is similar but not identical to L. tropica, isolates have been obtained from Procavia capensis (Grove and Ledger 1975), the hyrax present in Kenyan, Israeli and Jordanian foci (Ashford and Sang 2001, Jacobson et al. 2003, Kamhawi et al. 1995).

One way to circumvent this problem is by collecting sand flies from animals used as baits and to see whether the putative vectors have predilections or preferences. In the Laikipia focus in Kenya, $P$. guggisbergi, the proven vector, was collected from indigenous large animals such as goats, sheep and dogs, cats, rabbits and hyraxes (Procavia capensis); smaller rodents, giant rat (Cricetomys gambianus), crested rat (Lophiomys imhausi) and the exogenous hamster (Johnson et al. 1993). All the animals, except the hyrax and hamster, attracted significantly more sand flies than an empty cage control. The 


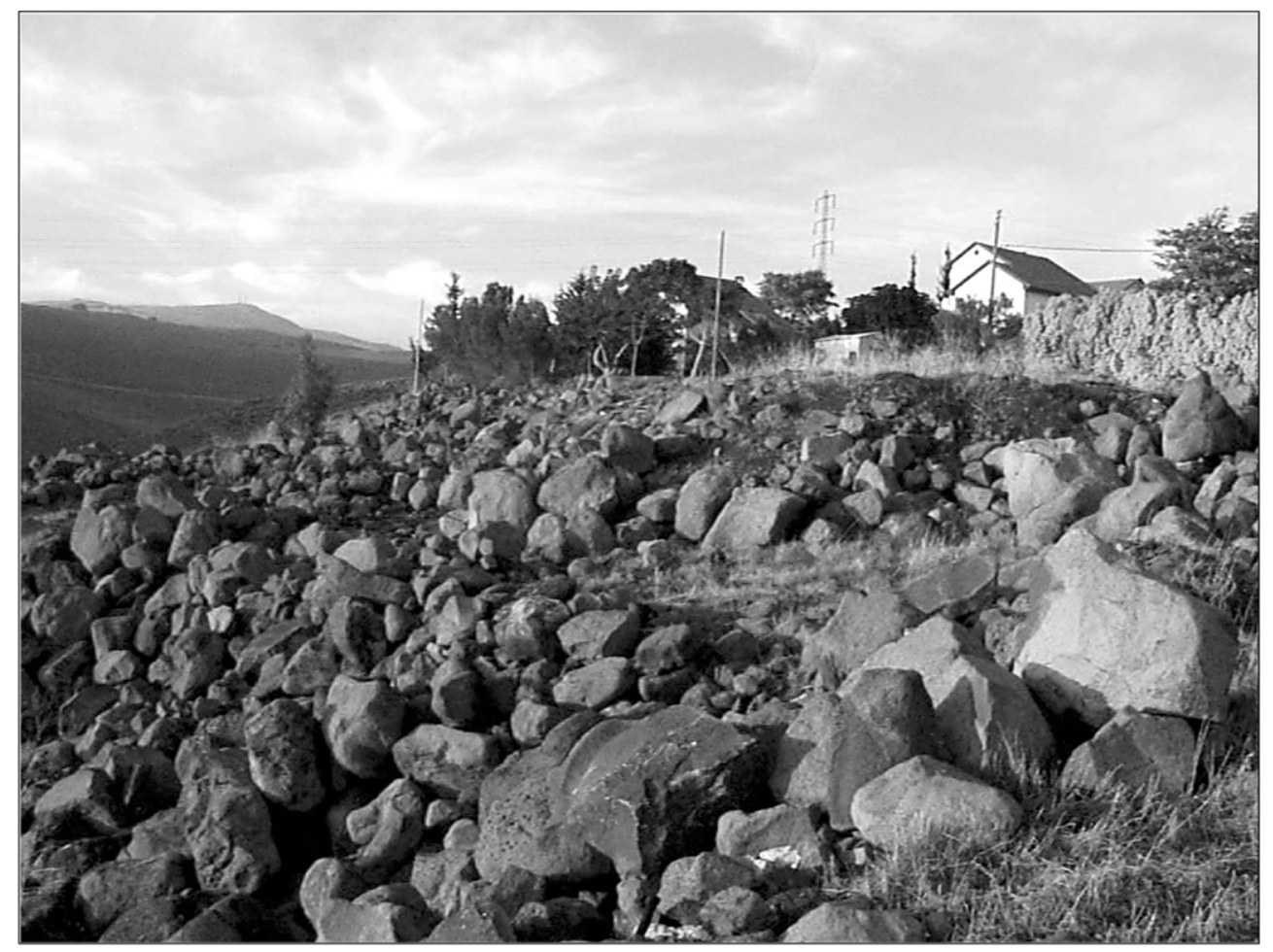

Fig. 2. A view of a typical breeding site of phlebotomine sand flies at a Leishmania tropica focus in Northern Israel. The sand flies breed between the basalt rocks that surround the village and have been found infected.

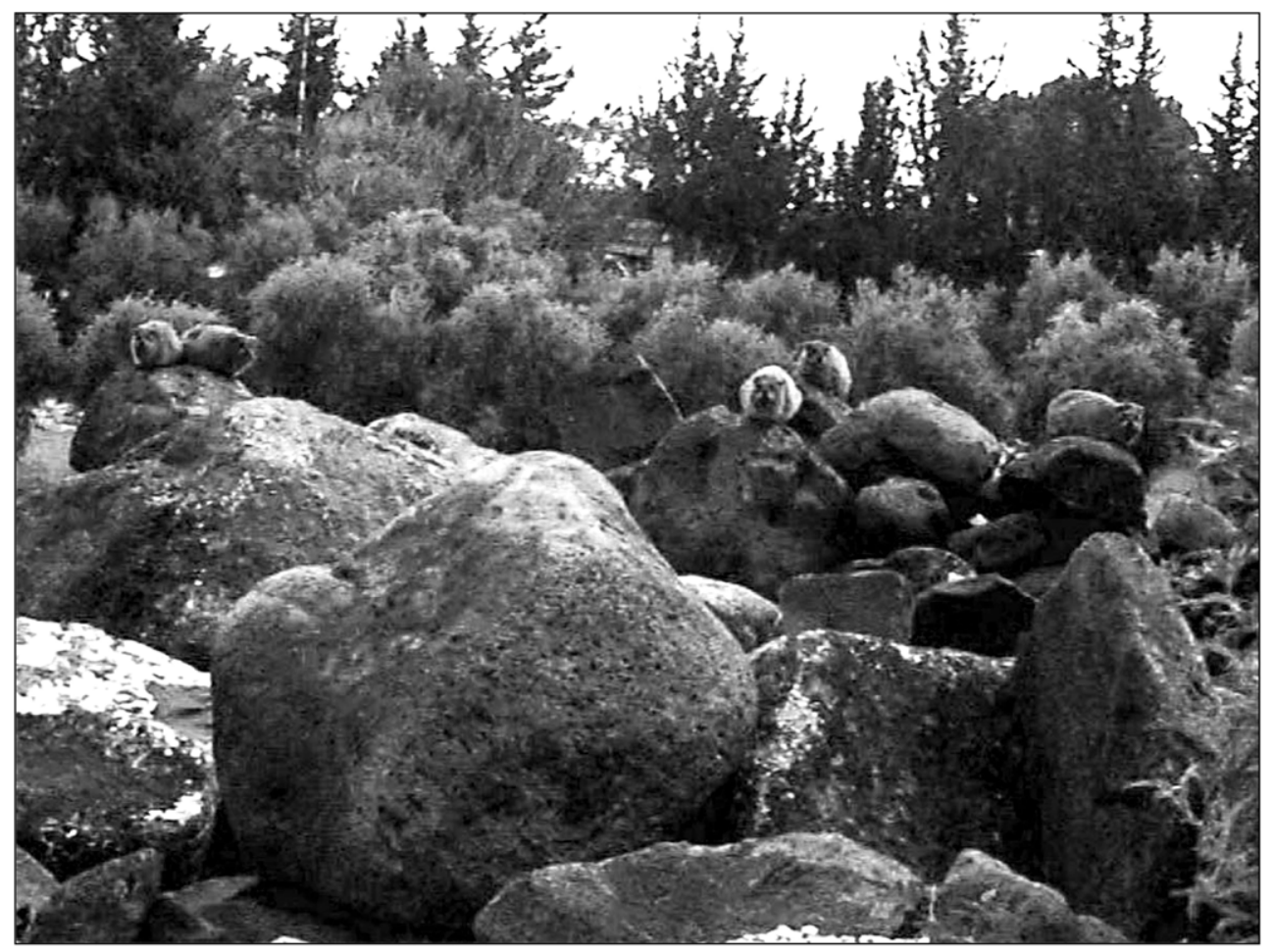

Fig. 3. In Northern Israel, rock hyraxes (Procavia capensis) have colonised the rocky terrain close to where an outbreak of cutaneous leishmaniasis occurred. Leishmania tropica parasites were isolated from hyraxes caught nearby. 
goat was far more attractive than the other animals even adjusting for size, suggesting it as a possible reservoir. The hyrax was one of the least attractive and it was dismissed as a reservoir as previous observed negative data on this animal reinforced the authors' views. While leishmaniasis has been described from a goat in Narok District of Kenya (Mutinga et al. 1989), it appears to be very rare and is probably not $L$. tropica (Williams et al. 1991). Cutaneous leishmaniasis was reported from a sheep in Eastern Transvaal in South Africa, but the parasite was not characterized (Van der Lugt et al. 1992). Another unusual report is that of Leishmania-like organisms associated with dermatitis in cattle in Zimbabwe (Bwangmoi et al. 1995, Dubey et al. 1998), a country where the disease is unknown, and in an animal that was once suggested as a possible reservoir host for visceral leishmaniasis (Killick-Kendrick 1990).

Our own experience with reservoir incrimination from an endemic focus in the Judean Hills, $15 \mathrm{~km}$ east of Jerusalem, has also been mixed. We have thoroughly examined 40 rodents and 3 hyraxes and were unable to obtain any Leishmania parasites from a multiplicity of tissue samples. We did however find high antibody titres to Leishmania in 3 Mus musculus and a Suncus etruscus, (pygmy white-toothed shrew), while all rats, hyrax and Acomys russatus (golden spiny mouse) were negative.

Until recently, animal models for studying $L$. tropica s.s. had been a neglected field. The inbred laboratory mouse was thought to be difficult to infect, but outbred hamsters (Mesocricetus auratus) proved to be susceptible to infection when stationary phase promastigotes or amastigotes of strains isolated in Afghanistan were used (reviewed by Bastien and Killick-Kendrick, 1992). Following this, using isolates from other countries and enriching the inoculum with stationary phase metacyclic promastigotes, it was found that both $\mathrm{BALB} / \mathrm{c}$ mice and hamsters were susceptible to L. tropica (Lira et al. 1998).

Another approach is to capture animals in an endemic area and try to infect them with the local strains of L. tropica. This has recently been done most elegantly after failure to find reservoir or infected vectors in the endemic focus of Urfa in southern Anatolia in Turkey. Svobodová et al. (2003) used a colony of Rattus rattus from Urfa and infected them with strains from human cases from the same area. Although the rats did not develop lesions, parasites could be re-isolated from the inoculated sites, ears and footpads up to 12 months post inoculation. The parasite load in the rats was monitored by using quantitative real-time PCR of Leishmania kDNA and it was shown that the parasite DNA was present in the tail, for example, throughout a two-year follow-up. The density of parasites ranged from $7.5 \times 10^{3}$ to $6 \times 10^{4}$ per $\mathrm{cm}^{2}$ of tissue and the question arose whether this was enough to infect sand flies. Sand flies from a colony of $P$. sergenti, originating from Urfa, were fed on the infected rats and $8 / 10$ transmitted the parasites to the flies, and though the infection rate was relatively low (range 0-7\%), it was well within accepted limits for transmission studies.

In our own studies both feral Rattus rattus and inbred white rats were susceptible to local strains of L. tropica, but made poor models. No external lesions were observed in any of the rats injected with L. tropica. White rats were negative for over two months by smear and culture. However, after three months parasites were cultured from footpads, ears, nose, lymph glands and spleen following necropsy. These isolates were checked by serotyping and were identical to the original strain. Cultures from $R$. rattus footpads were positive for two months following injection, but were negative at necropsy after three months. Serum antibody levels specific for Leishmania were elevated in only some of the rats (unpublished data).

\section{MODERN TRENDS}

Characterisation of Leishmania isolates has changed dramatically in the last 20 years. The advent of serological techniques, using both polyclonal and monoclonal antisera, was used initially to separate L. tropica from $L$. major (Jaffe and Sarfstein 1987, Schnur et al. 1990), but other biochemical methods demonstrated differences within the species (Chance and Walton 1982, Jacobson 1994). The "gold standard" was eventually achieved when isoenzyme electrophoretic methods, using 15 or more enzymes, were applied to differentiate between the diverse strains (Le Blancq and Peters 1986, Rioux et al. 1990). Presently there are approximately 30 defined zymodemes for $L$. tropica as compared to 12 for $L$. major s.s. No other Old World Leishmania species appears to have so much isoenzymic polymorphism, with diverse zymodemes being described even within the same focus (Pratlong et al. 1991) and with such frequency (Lemrani et al. 2002).

Most recently, the utilisation of DNA-based molecular technology has permitted a closer investigation of the genotype of this parasite. While standard PCR techniques are available for Leishmania species-specific separation, techniques such as permissively primed intergenic polymorphic-polymerase chain reaction (PPIP-PCR) that amplifies species-specific genomic DNA, have shown distinct geographical differences from isolates within a relatively small area (Eisenberger and Jaffe 1999). Genetic heterogeneity has also been emphasised for this species by diagnostic PCR-based techniques, PCR-finger printing and by amplification and analysis of the single-strand conformation polymorphisms of the ribosomal internal transcribed spacer 1 (SSCP-ITS1) (Schönian et al. 2001). SSCP analysis is able to detect single base-pair differences, which has been used to confirm the uniqueness of individual strains when compared to a wide range of other $L$. 
tropica isolates (Jacobson et al. 2003). These techniques showed that L. tropica could not be grouped geographically nor was there any correlation with zymodemes derived from isoenzyme electrophoresis.

The future for research in the laboratory will include the use of microsatellite markers that have already been developed for the L. donovani complex (Jamjoom et al. 2002) and L. infantum (Bulle et al. 2002).

However, it is imperative that research will not be restricted to the molecular dissection of this unusual parasite, but that the classical studies that include the sand fly vector, the animal reservoirs and different isolates of L. tropica will also continue. Human activity can enhance the likelihood of disease emergence by a diversity of interacting environmental pathways. Denser human populations come in closer contact with potential reservoir hosts while environmental deterioration can lead to increased numbers of sand flies that feed on animals and humans. Therefore, epidemiological and ecological studies that assess risk factors for spread of the disease and formulate preventive measures are of the utmost importance.

\section{CONCLUSIONS}

Leishmaniasis was once described as the "Cinderella" of tropical diseases, often left to a handful of researchers. Today the number of scientists or "Leishmaniacs", as they are sometimes called, that work on these parasites has grown exponentially in all the various disciplines. L. tropica is one of the least studied and may yet to prove to be the most interesting. It causes both cutaneous and visceral leishmaniasis, it is both anthroponotic and zoonotic, and now has several known phlebotomine vectors from different subgenera. It is so heterogeneous that some have suggested there are mutations associated with genetic exchange (Pratlong et al. 1991). The limits of its distribution are ill defined and it may well be spreading insidiously unknown to the public health authorities that will ultimately have to control the disease. While L. major has become a favourite model for the immunologists, the mammalian immune response to L. tropica has never been studied thoroughly and an open field awaits the intrepid investigator. The strains found in Namibia need a brave taxonomist to define them once and for all as perhaps a new species. The position of L. killicki as a separate species or subspecies of L. tropica should be validated. The search for more infected animals in the zoonotic foci would corroborate whether the hyrax is only one of the potential sources or the sole reservoir of this perplexing parasite.

Acknowledgements. I wish to thank Drs. C.L. Eisenberger and G. Schönian for their critical comments and Dr. A. Warburg and Dr. Eisenberger for providing the photographs. Parts of the research quoted was supported by grant no. SO 220/5-1 from the Deutsche Forschungsgemeinschaft (DFG): "The Palestinian-Israeli-German Cooperative Project on Leishmaniosis in Israel and The West Bank".

\section{REFERENCES}

ADLER S., THEODOR O. 1929: Attempts to transmit Leishmania tropica by bite: the transmission of L. tropica by Phlebotomus sergenti. Ann. Trop. Med. Parasitol. 22: 118.

ADLER S., THEODOR O., WITENBERG G. 1938: Investigations on Mediterranean Kala Azar XI. A study of leishmaniasis in Canea (Crete). Proc. R. Soc. Lond., Ser. B., 125: 491-516.

ALVAR J., CANAVATE C., GUTIERREZ-SOLAR B., JIMENEZ M., LAGUNA F., LOPEZ-VELEZ R., MOLINA R., MORENO J. 1997: Leishmania and human immunodeficiency virus coinfection: The first 10 years. Clin. Microbiol. Rev. 10: 298-319.

Al-ZAHRANI M.A., PETERS W., EVANS D.A., CHIN C., SMITH V., LANE R.P. 1988: Phlebotomus sergenti, a vector of Leishmania tropica in Saudi Arabia. Trans. R. Soc. Trop. Med. Hyg. 82: 416.

Al-ZAHRANI M.A., PETERS W., EVANS D.A., SMITH V., CHING C.I. 1989: Leishmania infecting man and wild animals in Saudi Arabia. 5. Diversity of parasites causing visceral leishmaniasis in man and dogs in the south-west. Trans. R. Soc. Trop. Med. Hyg. 83: 503-510.

ASHFORD R.W., DESJEUX P., DERAADT P. 1992: Estimation of population at risk of infection and number of cases of leishmaniasis. Parasitol. Today 8: 104-105.
ASHFORD R.W., SANG D.K. 2001: Review of Leishmania tropica infection in East Africa. Proceedings of the Second International Congress on Leishmania and Leishmaniosis, May 20-24, 2001, Hersonissos, Crete, Greece, p. 14.

BASTIEN P., KILLICK-KENDRICK R. 1992: Leishmania tropica infection in hamsters and a review of the animal pathogenicity of this species. Exp. Parasitol. 75: 433-441.

BEN-ISMAIL R. 1994: Rapport de fonctionnement. Laboratoire d'Epidemiologie et d'Ecologie Parasitaire. Arch. Inst. Pasteur Tunis 71: 86-107.

BRAY R.S., ASHFORD R.W., BRAY M.A. 1973: Parasite causing cutaneous leishmaniasis in Ethiopia. Trans. R. Soc. Trop. Med. Hyg. 67: 345-348.

BRAY R.S., DABBAGH M.A. 1968: Investigations into the epidemiology of leishmaniasis. Unsuccessful search for the reservoir host of kala-azar in Baghdad. J. Trop. Med. Hyg. 71: 46-47.

BULLE B., MILLON L., BART J.M., GALLEGO M., GAMBARELLI F., PORTUS M., SCHNUR L., JAFFE C.L., FERNANDEZ-BARREDO S., ALUNDA J.M., PIARROUX R. 2002: Practical approach for typing strains of Leishmania infantum by microsatellite analysis. J. Clin. Microbiol. 40: 3391-3397. 
BWANGMOI O., BUSAYI R., COURTNEY S.P. 1995: Cutaneous leishmaniasis in a calf in Zimbabwe. Zimbabwe Vet. J. 26: 144.

CHANCE M.L., WALTON B.C. (Eds.) 1982: Biochemical characterization of Leishmania. Proceedings of a Workshop held at Pan American Health Organization, Washington, DC, 9-11 December 1980. UNDP/World Bank/WHO, Geneva, 205 pp.

DAVIDSON I.H. 1993: Multivariate discrimination of Afrotropical females in the subgenus Synphlebotomus, putative vectors of leishmaniasis in subsaharan Africa (Diptera, Psychodidae, Phlebotominae). In: M. Coetzee (Ed.), Entomologist extraordinary: festschrift in honour of Botha de Meillon. South African Institute for Medical Research, Johannesburg, pp. 18-29.

DEREURE J., RIOUX J.A., GALLEGO M., PÉRIERÈS J., PRATLONG F., MAHJOUR J., SADDIKI H. 1991b: Leishmania tropica in Morocco: infection in dogs. Trans. R. Soc. Trop. Med. Hyg. 85: 595.

DEREURE J., RIOUX J.-A., KHIAMI A., PRATLONG F., PÉRIERÈS J., MARTINI A. 1991a: Écoepidémiologie des leishmanioses en Syrie. 2 - Presénce, chez le chien, de Leishmania infantum Nicolle et Leishmania tropica (Wright) (Kinetoplastida - Trypanosomatidae). Ann. Parasitol. Hum. Comp. 66: 252-255.

DESJEUX P. 2001: The increase in risk factors for leishmaniasis worldwide. Trans. R. Soc. Trop. Med. Hyg. 95: 239-243.

DOBRZHANSKAYA R.S., KHUSEIINOVA Kh.Kh., SAF'IANOVA V.M., EMEL'YANOVA L.P., SUKHANOVA T.A. 1989: [The activization of an Ashkhabad focus of anthroponotic cutaneous leishmaniasis.] Med. Parazitol. Parazit. Bolezni 1989 (5): 71-74. (In Russian.)

DOWLATI Y. 1996: Cutaneous leishmaniasis: clinical aspect. Clin. Dermatol. 14: 425-431.

DUBEY J.P., BWANGAMOI O., COURTNEY S.P., FRITZ D.L. 1998: Leishmania-like protozoan associated with dermatitis in cattle. J. Parasitol. 84: 865-867.

EISENBERGER C.L., JAFFE C.L. 1999: Leishmania: identification of Old World species using a permissively primed intergenic polymorphic-polymerase chain reaction. Exp. Parasitol. 91: 70-77. (Erratum. Exp. Parasitol. 92: 159-160 [1999].)

EL-ADHAMI B. 1976: Isolation of Leishmania from a black rat in the Baghdad area, Iraq. Am. J. Trop. Med. Hyg. 25: 759-761.

GARIFALLOU A., SCHNUR L.F., STRATIGOS J.D., HADZIANDONIOU M., SAVIGOS M., STAVRIANEAS N., SERIE C. 1984: Leishmaniasis in Greece II. Isolation and identification of the parasite causing cutaneous leishmaniasis in man. Ann. Trop. Med. Parasitol. 78: 369375.

GROVE S.S. 1989: Leishmaniasis in South West Africa Namibia to date. S. Afr. Med. J. 75: 290-292.

GROVE S.S., LEDGER J.A. 1975: Letter: Leishmania from a hyrax in South West Africa. Trans. R. Soc. Trop. Med. Hyg. 69: 523-524.

GUESSOUS-IDRISSI N., BERRAG B., RIYAD M., SAHIBI H., BICHICHI M., RHALEM A. 1997: Leishmania trop- ica: etiologic agent of a case of canine visceral leishmaniasis in northern Morocco. Am. J. Trop. Med. Hyg. 57: 172173.

GUILVARD E., RIOUX J.A., GALLEGO M., PRATLONG F., MAHJOUR J., MARTINEZ-ORTEGA E., DEREURE J., SADDIKI A., MARTINI A. 1991: Leishmania tropica au Maroc. III - Role vecteur de Phlebotomus sergenti. A propos de 89 isolates. Ann. Parasitol. Hum. Comp. 66: 9699.

HEWITT S., REYBURN H., ASHFORD R., ROWLAND M. 1998: Anthroponotic cutaneous leishmaniasis in Kabul, Afghanistan: vertical distribution of cases in apartment blocks. Trans. R. Soc. Trop. Med. Hyg. 92: 273-274.

JACOBSON R.L. 1994: Lectin-Leishmania interaction. In: R.J. Doyle and M. Slikfin (Eds.), Lectin-Microorganism Interactions. Marcel Dekker, New York, pp. 191-223.

JACOBSON R.L., EISENBERGER C.L., SVOBODOVÁ M., BANETH G., SZTERN J., CARVALHO J., NASEREDEEN A., El FARI M., SHALOM U., VOLF P., VOTÝPKA J., DEDET J.-P., PRATLONG F., SCHÖNIAN G., SCHNUR L.F., JAFFE C.L., WARBURG A. 2003: Outbreak of cutaneous leishmania-sis in Northern Israel. J. Infect. Dis. 188: 1065-1073.

JAFFE C.L., SARFSTEIN R. 1987: Species-specific antibodies to Leishmania tropica (minor) recognize somatic antigens and exometabolites. J. Immunol. 139: 1310 1319.

JAMJOOM M.B., ASHFORD R.W., BATES P.A., KEMP S.J., NOYES H.A. 2002: Towards a standard battery of microsatellite markers for the analysis of the Leishmania donovani complex. Ann. Trop. Med. Parasitol. 96: 265270.

JOHNSON R.N., NGUMBI P.M., ROBERT L.L., ANJILI C.O., KILLICK-KENDRICK R., MEREDITH S.E.O. 1993: Phlebotomine sandflies of Kenya (Diptera: Psychodidae). II. Phlebotomus aculeatus as a probable vector of Leishmania tropica s.1. Ann. Trop. Med. Parasitol. 87: 541-543.

JOHNSON R.N., NGUMBI P.M., MWANYUMBA J.P., ROBERTS C.R. 1993: Host feeding preference of Phlebotomus guggisbergi, a vector of Leishmania tropica in Kenya. Med. Vet. Entomol. 7: 216-218.

KAMHAWI S., ABDEL H.S., ARBAGI A. 1995: A new focus of cutaneous leishmaniasis caused by Leishmania tropica in northern Jordan. Trans. R. Soc. Trop. Med. Hyg. 89: 255-257.

KAMHAWI S., MODI G.B., PIMENTA P.F., ROWTON E., SACKS D.L. 2000: The vectorial competence of Phlebotomus sergenti is specific for Leishmania tropica and is controlled by species-specific, lipophosphoglycan-mediated midgut attachment. Parasitology 121: 25-33.

KILLICK-KENDRICK R. 1990: Are cattle a reservoir host of kala-azar in India? Trans. R. Soc. Trop. Med. Hyg. 84: 754.

KILLICK-KENDRICK R., KILLICK-KENDRICK M., TANG Y. 1994: Anthroponotic cutaneous leishmaniasis in Kabul, Afghanistan - the low susceptibility of Phlebotomus papatasi to Leishmania tropica. Trans. R. Soc. Trop. Med. Hyg. 88: 252-253. 
KLAUS S., AXELROD O., JONAS F., FRANKENBURG S. 1994: Changing patterns of cutaneous leishmaniasis in Israel and neighbouring territories. Trans. R. Soc. Trop. Med. Hyg. 88: 649-650.

LAINSON R., SHAW J.J. 1987: Evolution, classification and geographical distribution. In: W. Peters and R. KillickKendrick (Eds.), The Leishmaniases in Biology and Medicine. Vol. 1. Biology and Epidemiology. Academic Press, London, pp. 1-120.

LAWYER P.G., MEBRAHTU Y.B., NGUMBI P.M., MWANYUMBA P., MBUGUA J., KIILU G., KIPKOECH D., NZOVU J., ANJILI C.O. 1991: Phlebotomus guggisbergi (Diptera: Psychodidae), a vector of Leishmania tropica in Kenya. Am. J. Trop. Med. Hyg. 44: 290298.

Le BLANCQ S.M., PETERS W. 1986: Leishmania in the Old World. 2. Heterogeneity among L. tropica zymodemes Trans. R. Soc. Trop. Med. Hyg. 80: 113-119.

LEMRANI M., NEJJAR R., PRATLONG F. 2002: A new Leishmania tropica zymodeme - causative agent of canine visceral leishmaniasis in northern Morocco. Ann. Trop. Med. Parasitol. 96: 637-638.

LIRA R., MENDEZ S., CARRERA L., JAFFE C., NEVA F., SACKS D. 1998: Leishmania tropica: the identification and purification of metacyclic promastigotes and use in establishing mouse and hamster models of cutaneous and visceral disease. Exp. Parasitol. 89: 331-342.

LÜHE M. 1906: In: C. Mense (Ed.), Handbuch der Tropenkrankheiten. Vol. 3. J.A. Barth, Leipzig, p. 203.

MAGILL A.J., GROGL M., GASSER R.-A.,Jr., SUN W., OSTER C.N. 1993: Visceral infection caused by Leishmania tropica in veterans of Operation Desert Storm. N. Engl. J. Med. 328: 1383-1387.

MAGILL A.J., GROGL M., JOHNSON S.C., GASSER R.-A., Jr. 1994: Visceral infection due to Leishmania tropica in a veteran of Operation Desert Storm who presented 2 years after leaving Saudi Arabia. Clin. Infect. Dis. 19: 805-806.

MASSAMBA N.N., MUTINGA M.J., KAMAU C.C. 1998: Characterisation of Leishmania isolates from Laikipia District, Kenya. Acta Trop. 71: 293-303.

MEBRAHTU Y., LAWYER P., GITHURE J., KAGER P., LEEUWENBURG J., PERKINS P., OSTER C., HENDRICKS L.D. 1988: Indigenous human cutaneous leishmaniasis caused by Leishmania tropica in Kenya. Am. J. Trop. Med. Hyg. 39: 267-273.

MEBRAHTU Y., OSTER C.N., SHATRY A.M., HENDRICKS L.D., GITHURE J.I., REES P.H., PERKINS P.V., LEEUWENBURG J. 1987: Cutaneous leishmaniasis caused by Leishmania tropica in Kenya. Trans. R. Soc. Trop. Med. Hyg. 81: 923-924.

MUNIR M.A., RAB M.A., IQBAL J., GHAFOOR A., KHAN M.A., BURNEY M.I. 1989: A review of the status of leishmaniasis in Pakistan from 1960-1986. In: D.T. Hart (Ed.), Leishmaniasis. The Current Status and New Strategies for Control. Plenum Press, New York, pp. 4756.

MUTINGA M.J., KIHARA S.M., LOHDING A., MUTERO C.M., NGATIA T.A., KARANU F. 1989: Leishmaniasis in Kenya: description of leishmaniasis of a domestic goat from Transmara, Narok District, Kenya. Trop. Med. Parasitol. 40: 91-96.

OREN R., SCHNUR L.F., BEN YEHUDA D., MAYNER V., OKON E., RACHMILEWITZ E.A. 1991: Visceral leishmaniasis: a difficult diagnosis and unusual causative agent. J. Infect. Dis. 164: 746-749.

PRATLONG F., RIOUX J.-A., DEREURE J., MAHJOUR J., GALLEGO M., GUILVARD E., LANOTTE G., PERIERES J., MARTINI A., SADDIKI A. 1991: Leishmania tropica au Moroc. IV - Diversité isozymique intrafocale. Ann. Parasitol. Hum. Comp. 66: 100-104.

RIOUX J.A., LANOTTE G., PRATLONG F. 1986: Leishmania killicki n. sp. (Kinetoplastida, Trypanosomatidae). In: Leishmania. Taxonomy and phylogeny. Ecoepidemiological applications. IMEEE, Montpellier, pp. 139142.

RIOUX J.A., LANOTTE G., SERRES E., PRATLONG F., BASTIEN P., PERIERES J. 1990: Taxonomy of Leishmania. Use of isoenzymes. Suggestions for a new classification. Ann. Parasitol. Hum. Comp. 65: 111-125.

ROSS R. 1903: (1) Note on the bodies recently described by Leishman and Donovan. (2) Further notes on Leishman's bodies. Brit. Med. J. 2: 1261, 1401.

ROWLAND M., MUNIR A., DURRANI N., NOYES H., REYBURN H. 1999: An outbreak of cutaneous leishmaniasis in an Afghan refugee settlement in northwest Pakistan. Trans. R. Soc. Trop. Med. Hyg. 93: 133136.

SACKS D.L., KENNEY R.T., KREUTZER R.D., JAFFE C.L., GUPTA A.K., SHARMA M.C., SINHA S.P., NEVA F.A., SARAN R. 1995: Indian kala-azar caused by Leishmania tropica. Lancet 345: 959-961.

SÁDLOVÁ J., HAJMOVÁ M., VOLF P. 2003: Phlebotomus (Adlerius) halepensis vector competence for Leishmania major and Le. tropica. Med. Vet. Entomol. 17: 244-250.

SALIBA E., SALEH N., BISHARAT Z., OUMEISH O., KHOURY S., GRAMICCIA M., GRADONI L. 1993: Cutaneous leishmaniasis due to Leishmania tropica in Jordan. Trans. R. Soc. Trop. Med. Hyg. 87: 633.

SALIBA E.K., SALEH N., OUMEISH O.Y., KHOURY S., BISHARAT Z., Al-OURAN R. 1997: The endemicity of Leishmania tropica (zymodeme MON-137) in the EiraYarqa area of Salt District, Jordan. Ann. Trop. Med. Parasitol. 91: 453-459.

SANG D.K. 1991: Transmission of cutaneous leishmaniasis due to Leishmania tropica in Kenya. East Afr. Med. J. 68: 151-152.

SANG D.K., NJERU W.K., ASHFORD R.W. 1994: A zoonotic focus of cutaneous leishmaniasis due to Leishmania tropica at Utut, Rift Valley Province, Kenya. Trans. R. Soc. Trop. Med. Hyg. 88: 35-37.

SANG D.K., OKELO G.B.A., NDEGWA C.W., ASHFORD R.W. 1993: New foci of cutaneous leishmaniasis in central Kenya and the Rift Valley. Trans. R. Soc. Trop. Med. Hyg. 87: 629-632.

SCHLEIN Y., JACOBSON R.L. 1996: Why is man an unsuitable reservoir for the transmission of Leishmania major? Exp. Parasitol. 82: 298-305. 
SCHNUR L.F., NASEREDDIN A., EISENBERGER C.L., JAFFE C.L., El FARI M., AZMI K., ANDERS G., KILLICK-KENDRICK M., KILLICK-KENDRICK R., JACOBSON R.L., SCHÖNIAN G., WARBURG A. 2004: Diversity of Leishmania tropica isolates from Phlebotomus sergenti sand flies and humans in a Judean Desert focus. Am. J. Trop. Med. Hyg. (in press)

SCHNUR L.F., SARFSTEIN R., JAFFE C.L. 1990: Monoclonal antibodies against leishmanial membranes react with specific excreted factors (EF). Ann. Trop. Med. Parasitol. 84: 447-456.

SCHÖNIAN G., SCHNUR L., El-FARI M., OSKAM L., KOLESNIKOV A.A., SOKOLOWSKA-KÖHLER W., PRESBER W. 2001: Genetic heterogeneity in the species Leishmania tropica revealed by PCR-based methods. Trans. R. Soc. Trop. Med. Hyg. 95: 217-224.

SEHGAL S., SINHA R., MALLICK A., ARORA S.K., HAZRA P.K. 1992: Humoral antibody response in Leishmania tropica infection. J. Infection 24: 311-316.

SHARIFI I., FEKRI A.R., AFLATONIAN M.R., NADIM A., NIKIAN Y., KAMESIPOUR A. 1998: Cutaneous leishmaniasis in primary school children in the south-eastern Iranian city of Bam, 1994-95. Bull. WHO 76: 289-293.

SUNDAR S., PAI K., KUMAR R., PATHAK-TRIPATHI K., GAM A.A., RAY M., KENNEY R.T. 2001: Resistance to treatment in Kala-azar: speciation of isolates from northeast India. Am. J. Trop. Med. Hyg. 65: 193-196.

SVOBODOVÁ M., VOTÝPKA J., NICOLAS L., VOLF P. 2003: Leishmania tropica in the black rat (Rattus rattus): persistence and transmission from asymptomatic host to

Received 9 October 2003 sand fly vector Phlebotomus sergenti. Microbes Infect. 5: 361-364.

TAYEH A., JALOUK L., CAIRNCROSS S. 1997: Twenty years of cutaneous leishmaniasis in Aleppo, Syria. Trans. R. Soc. Trop. Med. Hyg. 91: 657-659.

THAKUR C.P., DEDET J.P., NARAIN S., PRATLONG F. 2001: Leishmania species, drug unresponsiveness and visceral leishmaniasis in Bihar, India. Trans. R. Soc. Trop. Med. Hyg. 95: 187-189.

Van der LUGT J.J., CARLYON J.F., DEWAAL D.T. 1992: Cutaneous leishmaniasis in a sheep. J. S. Afr. Vet. Assoc. 63: 74-77.

VOLF P., OZBEL Y., AKKAFA F., SVOBODOVÁ M., VOTÝPKA J., CHANG K.-P. 2002: Sand flies (Diptera: Phlebotominae) in Sanliurfa, Turkey: relationship of Phlebotomus sergenti with the epidemic of anthroponotic cutaneous leishmaniasis. J. Med. Entomol. 39: 12-15.

WIJESUNDERA M.S. 2001: Cutaneous leishmaniasis: an emerging health risk in Sri Lanka. Ceylon Med. J. 46: 151-152.

WILLIAMS A.O., MUTINGA M.J., RODGERS M. 1991: Leishmaniasis in a domestic goat in Kenya. Mol. Cell. Probes 5: 319-325.

WRIGHT J.H. 1903: Protozoa in a case of tropical ulcer ("Delhi sore"). J. Med. Res. 10: 472-482.

YAKIMOFF W.L., SCHOKHOR N.I. 1914: Récherches sur les maladies tropicales humaines et animals au Turkestan - II. La leishmaniose cutanée spontanée du chien au Turkestan. Bull. Soc. Pathol. Exot. 7: 186-187. 